January 2010

\title{
Why planning does not work? Land use planning and residents rights in Tanzania
}

Joe Lugalla

The Aga Khan University, joe.lugalla@aku.edu

Follow this and additional works at: http://ecommons.aku.edu/eastafrica_ied Part of the Urban Studies and Planning Commons

\section{Recommended Citation}

Lugalla, J. (2010). Why planning does not work? Land use planning and residents' rights in Tanzania. Review of African Political Economy, 37(125), 381-386.

Available at: http://ecommons.aku.edu/eastafrica_ied/85 


\title{
Why planning does not work? Land use planning and residents' rights in Tanzania
}

\author{
Joe L.P. Lugalla
}

To cite this article: Joe L.P. Lugalla (2010) Why planning does not work? Land use planning and residents' rights in Tanzania, Review of African Political Economy, 37:125, 381-386, DOI: 10.1080/03056244.2010.511786

To link to this article: http://dx.doi.org/10.1080/03056244.2010.511786

册 Published online: 05 Oct 2010.

6 Submit your article to this journal 2

Џll Article views: 208

Q View related articles $\leftarrow$ 


\section{BOOK REVIEW}

Why planning does not work? Land use planning and residents' rights in Tanzania, by Tumsifu Jonas Nnkya, Dares-Salaam, Mkuki na Nyota Publishers, 2007, 360 pp., £33.95. ISBN 9789987449682

In his book Why Planning Does Not Work? Nnkya deals with urban land-use planning and residents' rights in Tanzania. In brief, the book is about the politics of urban planning in Tanzania. It is a case study of how the politics of urban planning and the social organisation of space operate and continue to operate in Moshi town, situated in the northern part of Tanzania.

The introduction begins the book by discussing the technical process of urban planning and how it evolved in Tanzania, while remaining chapters deal with various aspects of urban planning as they developed in Moshi. Nnkya begins the second chapter with a thorough discussion of the genesis of the nature and form of the Moshi Master Plan that later became the epicentre of all the problems associated with urban planning. All other chapters that follow are linked to the Moshi Master Plan; for example, chapter three describes how the plan was adopted, chapter four relates the rationale made by officials for the Master Plan, who claimed it is 'for the sake of a good plan', and chapter five presents protests against the so-called 'good plan'. In all the remaining chapters Nnkya attempts to reveal the mechanics of the Master Plan and how it was implemented, put into practice, the social conflicts it generated, and the manoeuvres by officials to address these conflicts. He also exhibits how the officials became torn between safeguarding their own interests and getting legitimacy from the people by pretending that all their plans were in the best interests of the people.

Nnkya argues that the many land-use planning policies were being implemented in the context of the public land ownership policy of one political administrative system and a centrally planned economy (p. vii). According to Nnkya, 'though the public land ownership policy has remained unchanged, certain features of the policy with implications for land-use planning have changed'. On that same page, Nnkya asserts that 'over the past two decades, multi-party political system and market economy have replaced the single-party political system and command economy, respectively.' He maintains that this book deals with the dynamics of urban planning in the earlier political system of a command economy, then promises that his second book (which is yet to appear) will certainly focus on the way the politics of urban land-use planning manifest themselves under political pluralism and a liberal or market-oriented economy.

Nnkya begins by acknowledging that Tanzania is urbanising quickly 'in a situation of very limited capacity to cope with the requirements arising thereof' (p. vii). He strongly contends 'that urban growth is taking place increasingly unguided, regardless of the planning efforts to ensure managed urban spatial change.' A compelling critique asserts that the urban planning of the day is dominated by planners among the technocrats and has completely excluded those affected by 
planning decisions. In doing so, this system of land-use planning has disregarded people's land rights as well as the interest of the people. According to Nnkya, 'such a system of planning has ended up creating insecurity of land tenure and investments in land.' Moreover, it has also undermined people's initiative to improve their living conditions and eventually eradicate poverty.

Nnkya's case study of land-use planning in Moshi demonstrates that planning is both a technical and political interactive process involving planners as well as other actors in the political-administrative and judicial systems. He further argues that 'the decisions by the actors are not neutral but influenced by, inter alia, their self-interests which are sometimes pursued in the planning system at the expense of the society at large' (p. vii). He labels this form of planning 'technocratic, prescriptive, and non-inclusive'. Nnkya argues very correctly that the outcome of such planning has been people's lack of trust and confidence in the government - certainly with deleterious consequences on land development investments and people's welfare. What Nnkya seems to suggest, albeit indirectly, is that people's participation in urban land-use planning is important and usually yields better results.

At least at the phenomenal level, I am in complete agreement with Nnkya's sentiments concerning people's participation. Whether this is really happening in practice or will ever happen without radical transformation at the level of the dominant ideology are issues that remain to be seen. It is at this juncture that Nnkya and I take separate paths because our understanding of the essential relations that underlie all these problems seems to vary. Nnkya falls into the same problem he stood firm to criticise. He perceives planning as a technical process, and what it only lacks is the 'inclusion of people's voices'. I see things differently. I believe that planning is not neutral from ideology and is not apolitical. In a society divided along class lines, planning reflects the dynamics of class relations and usually tends to serve the interests of the dominant ideology - which in most cases is that of the dominant classes or those in power in society. Certainly there cannot be genuine people-participation in a class society. To assume that can happen is to anticipate that negotiations can take place between a hungry cat and a mouse. Despite the tendency for humans to negotiate, we cannot ignore the desire of those in power to maintain their power and resources. In situations where class relations define class interests, all attempts by the powerful to include the weak in planning are usually aimed at mystifying the reality and cushioning the inherent class contradictions. Certainly the motive is clear - to maintain the status quo and postpone the revolution which is likely to bring the power and social justice to the majority. Therefore, people's participation in this social context is mere abracadabra. What Nnkya lacks here is a historical analysis of how all this happened and continues to happen. To understand how these dynamics function in the developing world, and specifically in Tanzania, a historical account that examines the essence of dependent urbanisation is in order.

Over the last three decades, studies of urbanisation in the developing world have become of great interest to scholars of urban planning, human geography, urban sociology and urban anthropology. Interest in this area of study has been motivated by the need to understand the nature and pattern of urbanisation in the developing world which exhibit a contrast to the classical urbanisation that took place in Western Europe. While it can be argued that to a degree the urbanisation process of the West was a slow and gradual process associated with economic growth and social progress as well as a proper system of urban planning, the urbanisation process in the developing world is rapid, 
accompanied by a fast process of rural-tourban immigration causing the rapid growth of multi-million people cities. These factors prompt the mushrooming of spontaneous unplanned settlements of a slum-like nature, as well as squatter residential areas and massive poverty. Furthermore, third-world cities tend to accommodate administrative services rather than industrial production, and are therefore considered parasitic rather than generative. In this case, as opposed to cities in Western Europe, cities in developing countries do not produce surpluses and do not have a reciprocal linkage or economic or productive relationship with their rural hinterland. Instead, developing cities sustain themselves by exploiting their rural areas, facilitating the rapid growth of poverty in the rural areas which further generates a situation of despair and hopelessness for most rural dwellers often initiating rapid rural-urban migration. The rapid urbanisation overwhelms cities with many impoverished migrants, leading to problems with housing, urban planning, and adequate public services including water, electricity, street lights, schools and proper roads.

Some scholars have described this pattern of urbanisation as dependent in nature as it is an urbanisation process dictated by aborted capitalism that penetrated Africa via colonialism. Through the ideology of colonialism, cities were created in order to fulfil and champion the interests and objectives of colonists. African cities were a product of colonial ideology and their purpose was to serve the colonial economy, which created and intensified class differences. The misfortunes of these cities reflected the inequitable class structure in those societies and generated planning patterns that reflected those class relations. Urban planning became a tool through which the interests of those in power were articulated and achieved in terms of urban land-use patterns. One can argue that in the forgoing context, urban planning was not a purely technical process neutral from politics or class ideology, but, indeed, was a tool that was used to facilitate those inequalities and class interests. Sub-Saharan African cities are a product of the legacy described above and Tanzania is no exception.

Most, if not all, cities in Tanzania were planned and built by the colonial government with the objective of serving the colonial economy. Some emerged as administrative centres for colonial rule, while others as ports and commercial centres. Cities often emerged at crossroads or railway lines, and some in mining areas. Many others grew as a result of the role they played in export crops. The physical structure of these cities reflected the logic of colonial mentality and development. Since each colonial economic undertaking was essentially a planned one, even the towns were a product of planning. Towns were designed in such a way that their physical layout reflected the social distances of hierarchical colonial social organisation, allowing domination through racial and class segregation. During colonialism, Europeans lived in attractive suburbs comprised of large and expensive houses with spacious gardens. Streets were maintained and had streetlights. Houses were supplied with water, electricity and modern sewage connections. Golf courses, social clubs and other recreational facilities surrounded these luxurious residential areas.

Unfortunately, independence did not radically transform this legacy. Despite attempts to eradicate the colonial legacy by introducing the concepts of socialism and self-reliance through the Arusha Declaration, the practical implementation of this policy failed. Planning in general, and urban planning in particular, continued to be implemented along the lines and principles set by colonialism. Residential segregation continued unabated.

The first post-independent Master Plan (MP) for Dar-es-Salaam was published in 1968, eight years after independence and 
20 years after the former plan was introduced by Sir Alexander Gibb in 1948. This plan was produced one year after Tanzania had decided to cultivate socialist principles, but contrary to that aspiration they remained neo-colonial. The MP for Dodoma was published in 1976. It very closely resembled the MP for Dar-esSalaam in several ways. First, they were both prepared by the same company after Tanzania had decided to build socialism. Both MPs recommended Western models of city planning. However, it is in their planning of residential areas and provision of housing that the ideologies of these planning consultants are clearly revealed. Both plans identified three types of residential areas in the city and used the following planning concepts to describe the nature of these residential areas: 'high standard', 'medium standard' and 'low standard'. Contemporary master plans have replaced these terms with 'low density', 'medium density' and 'high density' residential areas, respectively. In plain terms, these planning schemes represent residential areas for the rich, middle and poor income people.

It is within this context that we need to understand the dynamics of urban planning in Tanzania. This analysis helps us to understand why planning works the way it does. The conflicts and politics that surround urban planning in Tanzania are a legacy of stratified ideology. The struggles we see happening at the urban level as far as land is concerned are class struggles that manifest themselves at the level of urban land-use planning. The zoning systems of urban planning, the squatter upgrading schemes, the site and service schemes, as well as the slum clearance programs explain, albeit furtively, both the nature, form and essence of these struggles. The grabbing of land owned by the poor in the name of public interest by those who are in power in a way helps us to understand how the ideology of those who are dominant shapes the political superstructure and influences the way the state designs its urban politics and policies. A few years ago, Tanzanians witnessed former affluent European residential houses that became public property at independence being sold to government officials of the Third Republic at a knock-down price. These are concrete examples that help us to understand that, to assume that the state is there to articulate public interests is indeed to assume too much. The state is not nonpartisan, but plays a specific role that is compatible with the hegemony of the ideology of the ruling class. As evinced by the aforementioned role of the state, public interests are in most cases never a priority.

Nnkya's book lacks this mode of analysis, and as a result, my distinguished colleague fails to see the role of the state or government in a neo-colonial society with a dependent economy. In his own words, Nnkya asserts that: 'Urban and regional planning is one of the mechanisms through which governments intervene in the change of the built and natural environment so as to ensure social equity and justice; orderly spatial development; safety; efficiency, convenience; and harmonious relation between development and the environment' (p. 1). The government also claims to conduct these services, but in reality they usually have their own hidden agendas. There is no doubt that the state in Tanzania is still neo-colonial and dependent, and the policies it pursues, its contradictions, and its weaknesses reflect that legacy. If the government of Tanzania were actually doing all the positive things that Nnkya describes above, all the nice and valid arguments that he presents in his book would be null and void. Even the title of his book, if not the book itself, would be redundant. Additionally, Nnkya also fails to see that the policies of urban planning themselves, the master plans and the ideology behind them (zoning system, building codes, and so on), are essentially alien to Tanzania. They have been superimposed onto Tanzanian culture and are not a product of independent, internal social 
relations that have been developed by Tanzanians themselves. The plans are a continuation of dependent and neo-colonial policies, playing a specific role in society and serving very well the interests of those in power. It is no wonder that we sometimes see 'ill plans' being labelled as 'good plans'. Also common is to see master plans that promote capitalist values of residential segregation by class, like the one for Dodoma being labelled as 'socialist' in a country that has failed to become a socialist one. With this analysis, one can understand why a country that vowed to build socialism and a new capital city (Dodoma) contracted a firm from a capitalist country - Project Planning Associates of Canada - to design a Master Plan of Dodoma that was supposed to reflect socialist values. It is important to know that all these weaknesses that are inherent in the system of urban planning do not happen by accident, but are a product of contradictions that become manifest in a political economy that has embraced the legacy described above.

Additionally, I want to note that corruption, kickbacks, connections, issues of technical abilities and inefficiency of some government bureaucrats have made the situation worse, as mentioned by Nnkya. There was a time when urban planning was efficient and corruption-free. Surveys of plots and their allocation to people who wanted them were quick and bribes were unheard of. Cities and towns were clean and everyone performed his or her duty for which they were responsible. Since around the mid 1980s, the ethics of doing things has changed in Tanzania. The country has been riddled with corruption, which has penetrated almost all government institutions including law enforcement institutions like the police and the judiciary - among others. In urban planning we are now witnessing a situation in which getting a building plot in an urban area is a lucrative business venture. Besides paying bribes, one has to be well connected. Even once one succeeds in getting a building plot, sometimes there are double allocations. Furthermore, navigating government bureaucracy in order to get a title deed and approval of a building plan not only involves official fees, but also bribes, connections and influence. Those who are poor can hardly succeed in such a system. As Nnkya accurately describes, land disputes are common and, due to corruption, they take many years to be resolved. We all know that justice delayed is justice denied, and at the end of the day those who have power, influence and money usually win. All these things reflect the weakness of a neo-colonial state in the era of globalisation. Those who control the economy control both the political life as well as the social life of the majority.

Despite my brief theoretical critique of Nnkya's book, I strongly support Why Planning Does Not Work? It is a very powerful piece that provides an ample amount of new knowledge in the area of urban land-use planning. It is a wellwritten, must-read book from the perspective of an urban planner. This book is not only important for urban planners, but also for other people who are involved in policy planning in Tanzania. I would like to see this book being used in universities that offer courses on urbanisation, rural and urban planning, urban sociology, urban anthropology and development planning in general. What Nnkya has provided in his book is a real, non-fiction account of urban land-use planning. That Nnkya is now Director of Housing in the Ministry of Lands and Human Settlements in Tanzania is a very positive advantage. He will certainly bring the good ideas that he presents in this book to his office in an attempt to change the current momentum in his ministry. If he succeeds in doing so, his ideas will not only remain in the library, but, we, the people of Tanzania, will celebrate his legacy and our fortune to have Nnkya not only as a scholar but also a practitioner. I have no doubt that 
everyone will desire this outcome upon Joe L.P. Lugalla reading his fabulous ideas that put the interests of those who lack power and influence at the forefront.

Email: jlpl@cisunix.unh.edu (C) 2010, Joe L.P. Lugalla 